\title{
Behavioral responses of tadpoles of Duttaphrynus melanostictus (Anura: Bufonidae) to cues of starved and fed dragonfly larvae
}

\author{
Santosh M. Mogali, Srinivas K. Saidapur, and Bhagyashri A. Shanbhag \\ Department of Zoology, Karnatak University. Dharwad-580 003, Karnataka State, India \\ E-mail: santoshmogali@rediffmail.com.
}

\begin{abstract}
Behavioral responses of tadpoles of Duttaphrynus melanostictus (Anura: Bufonidae) to cues of starved and fed dragonfly larvae. Tadpoles of Duttaphrynus melanostictus use chemoreception to detect kairomonal cues and excretory metabolites from predatory anuran tadpoles (Hoplobatrachus tigerinus) that consume them. We describe here the behavioral responses of tadpoles of $D$. melanostictus to predatory dragonfly larvae (Pantala flavescens). The predator's kairomones (water conditioned by the starved predator) or its diet-derived metabolites released in excreta of predator after consumption of conspecific prey tadpoles were used to simulate predation risk. The tadpoles of $D$. melanostictus had no behavioral response to predator kairomones. However, the larvae reduced swimming movements and overall time spent in swimming, and had a higher burst speed/swimming velocity in response to water borne cues released from the excreta of predators fed conspecific prey. Thus, just the presence of dragonfly larvae does not elicit defense behaviors in tadpoles of D. melanostictus, but when predation risk is recognized as real (i.e., when tadpoles are exposed to excretory metabolites of predators fed conspecific tadpoles), defense behaviors are activated.
\end{abstract}

Keywords: Defense behavior, dietary cues, kairomones, Pantala flavescens, predatorprey interactions, tadpoles, Wandering Glider.

\footnotetext{
Resumo

Respostas comportamentais de girinos de Duttaphrynus melanostictus (Anura: Bufonidae) a sinais de larvas de libélula famintas e alimentadas. Os girinos de Duttaphrynus melanostictus usam a quimiorrecepção para detectar sinais cairomonais e metabólitos excretados por girinos predadores (Hoplobatrachus tigerinus) que os consomem. Descrevemos aqui as respostas comportamentais de girinos de D. melanostictus a larvas de libélulas predadoras (Pantala flavescens). Os cairomônios do predador (água condicionada pelo predador faminto) ou seus metabólitos derivados da dieta liberados nos excretas do predador após o consumo de girinos coespecíficos foram utilizados para simular o risco de predação. Os girinos de D. melanostictus não apresentaram resposta
} 
comportamental aos cairomônios dos predadores. Contudo, as larvas reduziram os movimentos de natação e o tempo total gasto na natação e apresentaram uma maior velocidade de partida e de natação em resposta a estímulos transmitidos pela água liberados dos excretas de predadores que se alimentaram de presas coespecíficas. Assim, apenas a presença de larvas de libélula não elicia comportamentos de defesa nos girinos de D. melanostictus, mas os comportamentos de defesa são ativados quando o risco de predação é reconhecido como real (isto é, quando os girinos são expostos a metabólitos excretados pelos predadores alimentados com girinos coespecíficos).

Palavras-chave: cairomônios, comportamento de defesa, estímulos alimentares, girinos, interações predador-presa, Pantala flavescens, planador-errante.

\section{Introduction}

In nature, predation is a significant selective force acting on prey that drives the evolution of strategies for assessment of predation risk and the development of antipredator defense strategies in order to optimize survival and fitness. Detection of predators before an encounter can give prey the opportunity to respond behaviorally and reduce the probability of being detected, and hence eaten (Lima and Dill 1990). However, inducing anticipatory antipredator behavior has direct energetic costs, as well as costs associated with reduced opportunity to feed, that affect growth and development of tadpoles (Lima and Dill 1990, Ferrari et al. 2010). Aquatic anuran tadpoles assess predation risk using chemosensory mechanisms before responding with defense behaviors (Saidapur et al. 2009, Ferrari et al. 2010, Mogali et al. 2012, 2015). Specifically, they perceive alarm cues released by injured prey, kairomones (chemicals originating from the body of predators), and dietary cues (excretory metabolites or substances of predators fed conspecific/heterospecific prey) to alter behavior to escape predation (Wisenden 2000, Hagman 2008, Schoeppner and Relyea 2009a, Mogali et al. 2011, Carlson et al. 2015, Scherer and Smee 2016).

In southern India, most anurans including the common toad, Duttaphrynus melanostictus (Schneider, 1799), breed in ephemeral ponds following south-western monsoon rains. This leads to the larvae of several species coexisting sympatrically (Saidapur 2001). Some of these tadpoles are carnivorous and even cannibalistic. For example, tadpoles of the Indian bullfrog, Hoplobatrachus tigerinus (Daudin, 1802), are voracious predators that hunt actively and also are cannibalistic (Saidapur 2001, Rajput et al. 2011). The ponds in this region also harbor many predatory aquatic insects such as water beetles, water scorpions, and dragonfly larvae. The larvae of the dragonfly Pantala flavescens (Odonata: Libellulidae) are "sit-and-wait" predators that move slowly and wait for the prey to approach before attacking. We have shown that toad tadpoles detect kairomones of tadpoles of $H$. tigerinus, as well as dietary metabolites or substances from a predator that consumed toad tadpoles (Saidapur et al. 2009, Mogali et al. 2011). Herein, we describe antipredator behavioral responses of tadpoles of $D$. melanostictus in the presence of dragonfly larvae.

\section{Materials and Methods}

Egg strings $(N=4)$ of Duttaphrynus melanostictus were collected from temporary ponds in and around the Karnatak University Campus, Dharwad, India $\left(15.44^{\circ} \mathrm{N}, 74.98^{\circ} \mathrm{E}\right)$, in June 2010. In the laboratory, they were placed in separate plastic tubs $(42 \mathrm{~cm}$ diameter and $16 \mathrm{~cm}$ depth) containing $10 \mathrm{~L}$ of aged tap water. All eggs hatched almost simultaneously at Gosner stage 19 (Gosner 1960) a day after their collection. Subsequently, hatchlings of the different clutches were mixed $(N=100$ per clutch $\times 4$ clutches $=400$ hatchlings) and reared in a glass aquarium $(75 \mathrm{~L} \times 45 \mathrm{~W} \times 15 \mathrm{H} \mathrm{cm})$ 
with $15 \mathrm{~L}$ of aged tap water. From this stock, tadpoles of similar size $(16.28 \pm 0.80 \mathrm{~mm}$ total length) and developmental stage (Gosner stages 27-28) were randomly chosen for the experiments. The final instar larvae of $P$. flavescens $(N=50 ; 30.2 \pm 1.3 \mathrm{~mm}$ total length) were obtained from the same ponds where the egg clutches were collected. Dragonfly larvae were individually reared in plastic bowls $(14 \mathrm{~cm}$ diameter and $7 \mathrm{~cm}$ depth) with $200 \mathrm{~mL}$ of aged tap water, to avoid cannibalism. Tadpoles in the stock tanks were fed boiled spinach. Dragonfly larvae were fed toad tadpoles. The behavioral responses of the prey were studied by exposing them to "stimulus solution" of either predator kairomones or dietary metabolites of predators fed conspecific tadpoles. The preparation of stimulus solutions was, as follows.

Preparation of kairomones.-Individual dragonfly larvae were placed in separate plastic bowls $(N=10$ bowls; $19 \mathrm{~cm}$ diameter and $7 \mathrm{~cm}$ depth) with $200 \mathrm{~mL}$ of aged tap water without food for $96 \mathrm{~h}$ to eliminate diet-derived excretory metabolites from the stimulus solution, resulting in a stimulus solution with only kairomones.

Preparation of dietary cues of conspecific origin.-Three dragonfly larvae were placed in plastic bowls ( $N=5$ bowls; $19 \mathrm{~cm}$ diameter and $7 \mathrm{~cm}$ depth) with $600 \mathrm{~mL}$ of aged tap water along with 12 toad tadpoles at Gosner stages 27-28 (at about 08:30 h). The dragonfly larvae consumed all the tadpoles provided to them by the evening $(18: 30 \mathrm{~h})$. On the following day between 09:30 $\mathrm{h}$ and 11:30 $\mathrm{h}$, predators were removed and the water from the bowls was filtered using fine cheese cloth. The filtrate served as the stimulus solution containing the diet-derived excretory metabolites or substances of predators fed conspecific prey and are unlikely to have contained the alarm cues of prey. Prey alarm cues are known to be labile in nature (Ferrari et al. 2008, Wisenden et al. 2009, Chivers et al. 2013). Thus, it is unlikely that prey alarm cues were present in the stimulus solution because all prey were consumed more than $15 \mathrm{~h}$ before the solution was collected.

\section{Behavioral Responses of Prey to Predator's Kairomones}

The behavioral responses of prey tadpoles to kairomones (water conditioned with starved predators) were recorded by placing single tadpole in a rectangular glass tank $(28 \mathrm{~L} \times 15 \mathrm{~W} \times 15 \mathrm{H}$ $\mathrm{cm})$ with $600 \mathrm{~mL}$ of aged tap water. A handycam (Sony, DCR-SR300/E) was positioned above the tank to record activity in the entire tank. The handycam was connected to a computer with the Ethovision Video Tracking System (Noldus Information Technology, The Netherlands) to track movements of the tadpole before and after addition of stimulus solution to the test tank. The Ethovision system was used to record maximum swimming speed $\left(V_{\max }\right)$, distance traversed by the tadpole, number of swimming spurts, and time spent swimming during an entire trial. For each trial, a tadpole put into the tank and left undisturbed for $5 \mathrm{~min}$. A burette was placed $\sim 1 \mathrm{~cm}$ above the water level and $50 \mathrm{~mL}$ of aged tap water (chemical blank) was then added at the rate of $\sim 1 \mathrm{~mL} / \mathrm{s}$. The burette was then removed gently. Movement of the tadpole was then recorded for 5 min using Ethovision to record its baseline activity in the absence of any cues. After tracking baseline activity, $50 \mathrm{~mL}$ of stimulus solution containing kairomones was added as described above. Movement of the tadpole was recorded for another 5 min to determine the activity pattern after exposure to kairomones.

\section{Behavioral Responses of Prey to Dietary Cues of Conspecific Origin}

In this experiment, the stimulus solution contained chemical cues from excretory metabolites or substances of dragonfly larvae fed toad tadpoles instead of only kairomones of the predator. The behavioral responses of tadpoles were recorded as described above, before and after the addition of stimulus solutions.

In both experiments, a total of 25 trials were run using a new tadpole each time. The test tank was cleaned and replenished with aged tap water between trials. 


\section{Statistical Analysis}

The data on $V_{\max }$, swimming spurts, time spent swimming and total distance traversed were $\log$ transformed prior to analysis to meet the assumption of normality. The behavioral responses of tadpoles before and after the addition of stimulus solutions (predator kairomones or diet-derived excretory metabolites) were compared using PairedSamples t-test. Statistical tests were performed using SPSS ver. 16.0.

\section{Results}

The $V_{\text {max }}(t=-0.373, d f=24, p=0.712$, Figure 1A), frequency of swimming spurts $(t=$ $0.528, d f=24, p=0.602$, Figure 1B), time spent swimming $(t=0.126, d f=24, p=0.901$, Figure $1 \mathrm{C})$ and total distance traversed $(t=0.123, d f=$ $24, p=0.903$, Figure 1D) by tadpoles exposed to chemical blank water were similar to those exposed to kairomones.

Upon exposure to diet-derived metabolites of a predator after it consumed conspecific prey, tadpoles showed a significant increase in $V_{\max }(t$ $=-5.092, d f=24, p<0.001$, Figure 2A), and significant declines in the number of swimming spurts $(t=7.154, d f=24, p<0.001$, Figure 2B), time spent swimming $(t=7.242, d f=24, p<$ 0.001 , Figure 2C) and total distance moved $(t=$ 6.879, $d f=24, p<0.001$, Figure 2D) when compared to their baseline activities in stimulusfree water.

\section{Discussion}

Tadpoles of Duttaphrynus melanostictus do not alter their behavior in response to only kairomones of predatory larvae of $P$. flavescens, thereby suggesting that they do not perceive cues of the dragonfly larvae as a serious predation threat. Similar results have been reported for tadpoles of Indosylvirana temporalis (Günther, 1864) (Mogali et al. 2012) and Euphlyctis cyanophlyctis (Schneider, 1799) (Supekar and
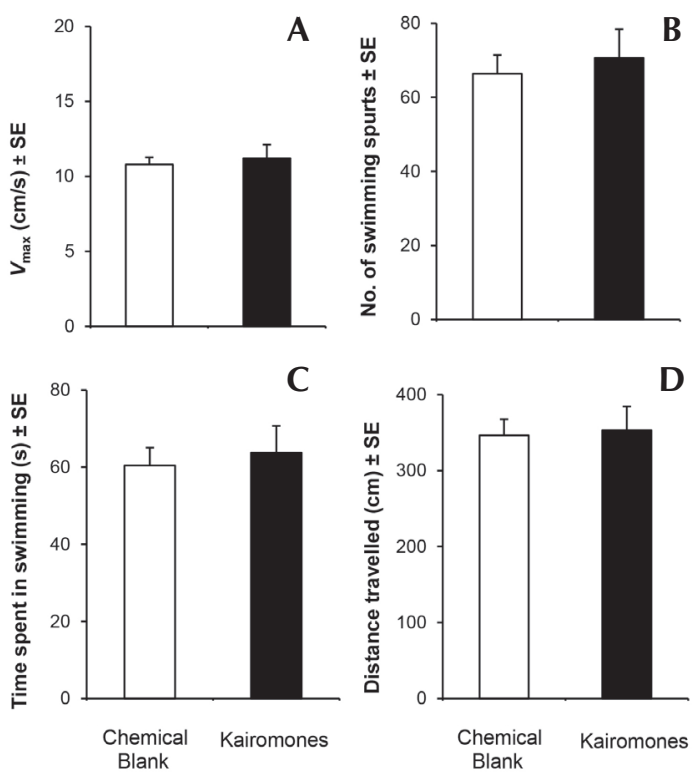

Figure 1. Maximum swimming speed $\left(V_{\max }\right) \quad(\mathbf{A})$, Swimming spurts (B), Time spent in swimming (C), and Distance travelled (D) by tadpoles of Duttaphrynus melanostictus exposed to chemical blank water (aged tap water) or kairomonal stimuli of Pantala flavescens. Data are represented as mean $\pm \mathrm{SE} ; N=25$ trials; data analyzed by Paired-Samples t-test.

Gramapurohit 2018). In contrast, toad tadpoles exhibit strong behavioral responses (i.e., reduced swimming movements and high burst speed) to kairomones of predatory sympatric tadpoles of Hoplobatrachus tigerinus (Mogali et al. 2011), which locate prey visually and prey on coexisting sympatric anuran tadpoles (Saidapur 2001, Saidapur et al. 2009). Thus, frog species such as $H$. tigerinus pose a serious predation threat. The long ecological coexistence of toad tadpoles with sympatric carnivorous tadpoles such as $H$. tigerinus may have led to the evolution of antipredator defense strategies in response to kairomones of these predators.

In contrast, larvae of dragonfly are "sit-andwait" predators that move slowly and usually wait for prey to come near before attacking 

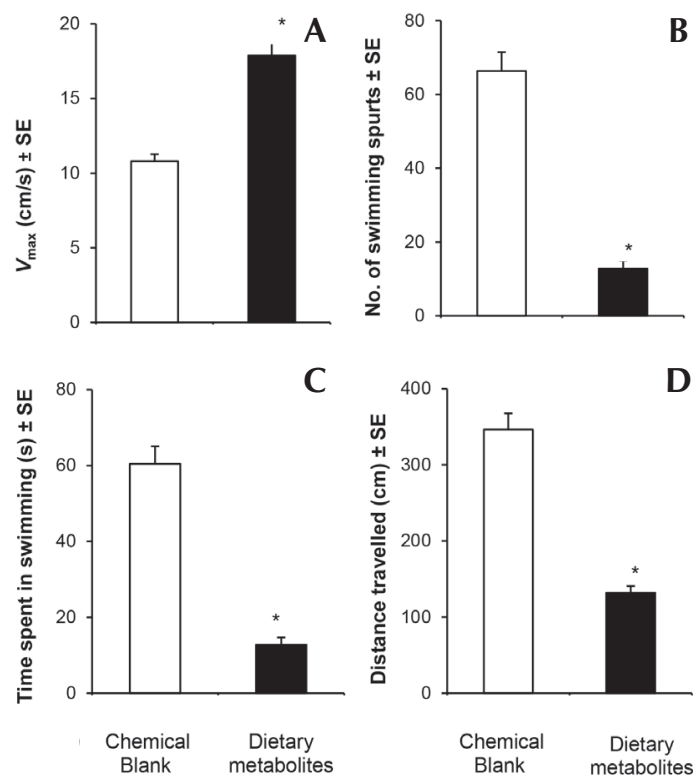

Figure 2. Maximum swimming speed $\left(V_{\max }\right)$ (A), Swimming spurts (B), Time spent in swimming (C), and Distance travelled (D) by tadpoles of Duttaphrynus melanostictus exposed to chemical blank water (aged tap water) or dissolved diet-derived excretory metabolites of conspecific prey fed Pantala flavescens. Data are represented as mean $\pm \mathrm{SE} ; \mathrm{N}=25$ trials; data analyzed by Paired-Samples t-test. Asterisks over the bars indicate significant difference between chemical blank water and diet-derived metabolites of predators from excreta groups.

(Miller et al. 2014). They seem to be perceived by the prey as less dangerous and they may pose a lower predation threat. There is intense selection pressure on "sit-and-wait" predators to suppress chemical (e.g., kairomones) evidence of their presence (Miller et al. 2015) because they need the prey to approach them closely. Also, it is possible that the predation pressure of dragonfly larvae on toad tadpoles is low. If so, toad tadpoles are better served by conserving their energy by not inducing antipredator defenses in response to kairomones, if any, of dragonfly larvae. In contrast, water-soluble substances in the excreta of larvae of $P$. flavescens following consumption of conspecific prey seems to indicate intense predation threat and elicit strong behavioral changes in toad tadpoles in the form of reduced swimming movements and high burst speed. Apparently, evidence of recent predation on conspecific members of the group indicates high predation risk for tadpoles in the vicinity.

Our results are consistent with those reported for tadpoles of Dryophytes versicolor (LeConte, 1825) (Schoeppner and Relyea 2009b). We rule out the influence of alarm cues released by toad tadpoles as there were neither surviving injured individuals nor dead remains of tadpoles in the bowls for $15 \mathrm{~h}$ prior to harvesting the stimulus solution, and alarm cues are highly labile in nature (Ferrari et al. 2008, Wisenden et al. 2009, Chivers et al. 2013). Hence, the antipredator defense behavior of toad tadpoles in the present study is specifically in response to diet-derived excretory metabolites or substances released by dragonfly larvae that have consumed conspecific prey. In conclusion, toad tadpoles can exhibit different behavioral responses to different predator-related cues.

\section{Acknowledgments}

The study was supported by a grant from Department of Science and Technology, New Delhi (No. SP-SO/AS-38/2009) awarded to BAS. SMM was supported as project assistant in the project. All work reported herein was conducted in accordance with ethical guidelines laid down by CPCSEA, New Delhi, India (registration no. 639/02/a/CPCSEA).

\section{References}

Carlson, B. E., J. C. Newman, and T. Langkilde. 2015. Food or fear: hunger modifies responses to injured conspecifics in tadpoles. Hydrobiologia 743: 299-308.

Chivers, D. P., D. L. Dixson, J. R. White, M. I. McCormick, and M. C. O. Ferrari. 2013. Degradation of chemical alarm cues and assessment of risk throughout the day. Ecology and Evolution 3: 3925-3934. 
Ferrari, M. C. O., F. Messier, and D. P. Chivers. 2008. Degradation of chemical alarm cues under natural conditions: risk assessment by larval woodfrogs. Chemoecology 17: 263-266.

Ferrari, M. C. O., B. D. Wisenden, and D. P. Chivers. 2010. Chemical ecology of predator-prey interactions in aquatic ecosystems: a review and prospectus. Canadian Journal of Zoology 88: 698-724.

Gosner, K. L. 1960. A simplified table for staging anuran embryos and larvae with notes on identification. Herpetologica 16: 183-190.

Hagman, M. 2008. Behavioral responses by tadpoles of six Australian species to chemical cues from other tadpoles. Herpetological Conservation and Biology 3: 239-246.

Lima, S. L. and L. M. Dill. 1990. Behavioral decisions made under the risk of predation: a review and prospectus. Canadian Journal of Zoology 68: 619-640.

Miller, J. R. B., J. M. Ament, and O. J. Schmitz. 2014. Fear on the move: predator hunting mode predicts variation in prey mortality and plasticity in prey spatial response. Journal of Animal Ecology 83: 214-222.

Miller, A. K., B. Maritz, S. Mckay, X. Glaudas, and G. J. Alexander. 2015. An ambusher's arsenal: chemical crypsis in the puff adder (Bitis arietans). Proceedings of the Royal Society B: Biological Sciences 282: 20152182.

Mogali, S. M., S. K. Saidapur, and B. A. Shanbhag. 2011. Levels of predation modulate antipredator defense behavior and metamorphic traits in the toad Bufo melanostictus. Journal of Herpetology 45: 428-431.

Mogali, S. M., S. K. Saidapur, and B. A. Shanbhag. 2012. Tadpoles of the bronze frog (Rana temporalis) assess predation risk before evoking antipredator defense behavior. Journal of Ethology 30: 379-386.

Mogali, S. M., B. A. Shanbhag, and S. K. Saidapur. 2015. Strong food odours mask predation risk and affect evocation of defence behaviours in the tadpoles of Sphaerotheca breviceps. Journal of Ethology 33: 4146.

Rajput, A. P., B. A. Shanbhag, and S. K. Saidapur. 2011. Absence of kin discrimination in cannibalistic anuran tadpoles of the frog Hoplobatrachus tigerinus (Daudin). Indian Journal of Experimental Biology 49: 362-365.

Saidapur, S. K. 2001. Behavioral ecology of anuran tadpoles: Indian scenario. Proceedings of the Indian National Science Academy B67: 311-322.

Saidapur, S. K., D. K. Veeranagoudar, N. C. Hiragond, and B. A. Shanbhag. 2009. Mechanism of predator-prey detection and behavioral responses in some anuran tadpoles. Chemoecology 19: 21-28.

Scherer, A. E. and D. L. Smee. 2016. A review of predator diet effects on prey defensive responses. Chemoecology 26: $83-100$.

Schoeppner, N. M. and R. A. Relyea. 2009a. Interpreting the smells of predation: how alarm cues and kairomones induce different prey defences. Functional Ecology 23: $1114-1121$

Schoeppner, N. M. and R. A. Relyea. 2009b. When should prey respond to consumed heterospecifics? Testing hypothesis of perceived risk. Copeia 2009: 190-194.

Supekar, S. C. and N. M. Gramapurohit. 2018. Larval skipper frogs recognise kairomones of certain predators innately. Journal of Ethology 36: 143-149.

Wisenden, B. D. 2000. Olfactory assessment of predation risk in the aquatic environment. Philosophical Transactions of the Royal Society B: Biological Sciences 355: 1205-1208.

Wisenden, B. D., M. L. Rugg, N. L. Korpi, and L. C. Fuselier. 2009. Lab and field estimates of active time of chemical alarm cues of a cyprinid fish and amphipod crustacean. Behaviour 146: 1423-1442.

Editor: Ross Alford 